\title{
Physico-chemical profile and phytoremediation of Ebony Paint Industrial Effluent using n-Hexane de-fattedMoringaoleifera Seed Powder
}

\author{
*Otuu, Fred C., Inya-Agha, Stella I., ${ }^{2}$ Ude, Clement C., ${ }^{3}$ Chukwu, Chinyere \\ C. ${ }^{4}$ Ani, Uchenna G. ${ }^{5}$ \\ Drug Delivery/Environmental Research Unit, Department of Pharmaceutics, University of Nigeria, Nsukka. \\ Department of Pharmacogonosy/Environmental Medicine, University of Nigeria, Nsukka \\ Department of Applied Biochemistry, Enugu State University of Science and Technology, Enugu \\ Annunciation Specialist Hospital, Emene, Enugu \\ Department of Estate Management, Faculty of Environmental Sciences, Enugu State University of Science and \\ Technology, Enugu, Nigeria
}

\begin{abstract}
Ebony Paints is a popular paint industry from where Ebony Paint Road, in Enugu, derives its name. Ebony paint road is a cluster settlement with high human density. Located directly opposite 103 Motoring Battalion of Nigerian Army, in Enugu East Local Government Area of Enugu State, South Eastern Nigeria, the area is also known for its high concentration of artisans and proliferation of shallow well water bodies. Effluent discharge from the Ebony Paint industry easily finds its way into the surrounding human settlements, exposing the inhabitants to pollution. In this work, the physico-chemical profiles and phyto-remediation of Ebony Paint effluent with N-Hexane de-fatted Moringa seed powder were studied. Pre-treatment analysis showed that the effluent was heavily polluted in terms of organoeleptic properties of odor and color as well as high turbidity (18.20), conductivity $\left(950 \mathrm{us} / \mathrm{cm}^{3}\right)$. Total solid $(1410.0 \mathrm{mg} / \mathrm{l})$, Acidity $(120.0 \mathrm{mg} / \mathrm{l})$. Post-treatment analysis showed significant improvement in the organoeleptic properties as well as turbidity (1.2), Total Solid (410mg/l), Acidity $(23.0 \mathrm{mg} / \mathrm{l})$. The $\mathrm{pH}$ was improved from 8.0 to 7.50 after treatment. $N$-hexane de-fatted seed powder, had phyto-remediation potential in Ebony Paint effluent.
\end{abstract}

Key words: Paint Effluent, N-Hexane de-fatted Moringa seed powder, phytoremediation, pollution.

\section{Introduction}

The production process of most paint companies is a batch process which involves the introduction of appropriate chemicals such as calcium carbonate, liquid ammonia, titanium dioxide, aluminum silicate, precipitate calcium carbonate, water, pine oil, DBP surfactant and de-foamer in appropriate proportion into the mixing pots where these chemicals and additives are homogenously mixed to correct proportions resulting into finished products which may be emulsion paints, oil paints, texture paints and Car paints. These are put in appropriate containers ranging from 4 to 20 litres as the case may be for distribution to customers (EHRL, 2012). In Nigeria the raw materials for production are 30\% imported, $70 \%$ locally sourced. Some companies produce an average of 600 dozens of different brands of paint per week, depending on the size of the company and the demands on the market (EHRL, 2012). Because of a line-up of raw materials and chemical reagents required in paint production, the problems of waste management are also enormous, resulting in some cases to generation of obnoxious and unaesthetic effluents into the environment.

In a developing society such as Nigeria where limited attention is given to public health and environmental health laws, most companies are more concerned with maximization of their profit at the expense of environmental sanitation (EHRL, 2012). While profit making remains the ultimate motive for starting any business enterprise or production outfit, efforts should also be made to achieve this result with minimal damage to the environment. One of these efforts includes treatment of the effluents prior to discharge into the environment. Most treatment procedures involve the use of synthetic coagulants such as Aluminum sulphate in a treatment pond (Dovletoglou and Grigoropoulou, 2002). Conventional effluent treatment using aluminum and other chemical coagulants for clarification and chlorine for disinfection are both expensive, environmentally unfriendly, and have been implicated in the etiology of many diseases. The dangers of by-products of alumchlorine interactions, such as tri-halo methane place serious disadvantage to their continuous uses. Globally, there is a serious search for alternative, reliable, environmentally and health friendly means of effluent treatment. One of these methods is the use of plant materials with coagulating properties. M. oleifera is an established coagulant in water turbidity removal (Angelica et al., 2010, Amir et al., 2010, Nnamaniet al 2012). 


\subsection{Sample processing}

\section{Methodology}

M. oleifera seeds were thoroughly checked for ant infestation and the infested ones removed. The seeds were sun dried for three days, after which they were pulverized with a laboratory blender. The pulverized seeds powder was de-fatted with N-Hexane by cold maceration, and stored in an air tight plastic container until used. Effluent sample was collected using pretreated stainless steel jug, and stored in a 10-litre dark plastic container in an ice bucket until used.

\subsubsection{Floc Formation}

Floc formation was achieved using mechanical stirrer. $500 \mathrm{ml}$ of the paint effluent sample was poured into 1 litre pyrex glass beakers. Seven sets, labeled control, $25 \mathrm{mg}, 50 \mathrm{mg}, 75 \mathrm{mg}, 100 \mathrm{mg}, 125 \mathrm{mg}$ and $150 \mathrm{mg}$ were made. The control set contained only paint effluent without M.oleifera seed powder, while the remaining six sets contained $500 \mathrm{ml}$ of the paint effluent plus the concentrations of the powder as labeled. After rapid mixing to disperse the powder, the samples were stirred at 70rpm for a minute and at a speed of 300rpm for 25 minutes. The sets were allowed to settle under quiescent condition for $12 \mathrm{hrs}$. The nature and settling characteristics of the floc formed were observed and recorded in qualitative terms as poor, fair and good. The flocculating property was compared with that of the control treated effluent.

\subsubsection{Total Dissolved Solids (TDS)}

The TDS was determined by the Direct Reading Engineering Method (DREM) using DANA multimeter, pre-calibrated according to the manufacturer's instruction. A $50 \mathrm{ml}$ volume of the paint effluent sample was introduced into $100 \mathrm{ml}$ glass beaker. The probe of the meter was dipped into the beaker, and the TDS mode activated by pressing gently on the meter's soft touch button. The value displayed at the LCD panel of the meter was allowed to stabilize and recorded as the true value of the reading.

\subsubsection{Total Suspended Solid (TSS)}

The total suspended solid was determined by the gravimetric method. Porcelain crucible was dried in an oven at $100^{\circ} \mathrm{c}$ to obtain a known constant weight $\mathrm{W}_{\mathrm{I}}$ A $50 \mathrm{ml}$ volume of the paint effluent sample was introduced into the crucible and the crucible heated in an oven at $100^{\circ} \mathrm{c}$ until the effluent sample vaporized. It was cooled in desiccators and reweighed to obtain $\mathrm{W}_{2}$.

The total suspended solid was calculated using the equation: - TSS $=\mathrm{W}_{2}-\mathrm{W}_{1} \quad \mathrm{X} \quad 100$

\subsubsection{Total Solid (TS)}

The total solid was obtained by calculating the arithmetic sum of the TSS and TDS.

\subsubsection{Turbidity Test}

The turbidity value was obtained directly from the total suspended solid (TSS), using the relationship Turbidity $=$ TSS

$$
\text { Vol. of water used }
$$

$=$

$$
50
$$

TSS

The value of TSS for the sample was divided by the volume of water used.

The $\mathrm{P}^{\mathrm{H}}$ of the sample was determined by the same Direct Reading Engineering Method (DREM) using the same Dana multi-meter. The probe of the meter was dipped into beaker of 50ml effluent sample, and the $\mathrm{P}^{\mathrm{H}}$ mode called up. The value displayed was taken as the true $\mathrm{P}^{\mathrm{H}}$ value.

\subsubsection{Colour}

The colour of the sample was determined by the sensory evaluation technique using panel of 10 adults (project students of Applied Biochemistry Department, ESUT), comprising of 5 ladies and 5 gentlemen of average age 25years. The reports were validated when up to half of the total number of participants reported the same thing.

\subsubsection{Odour}

The same technique as above was used, and the same numbers used in colour test were empanelled. They were used prior to treatment and after treatment with the seed powder. 


\subsubsection{Conductivity Test}

The same Dana multi-meter was used as previously described in other tests. The conductivity mode was called up on immersion of the sensory part of the probe in the sample, and the value displayed was recorded.

\subsection{Temperature}

Dana multi-meter was also used and the procedure was as in the other cases described above.

\subsubsection{Titratable Acidity (TA)}

This was determined by the volumetric method, according to the method of A.O.A.C, (2005). 100ml of the water sample in a conical flask was titrated against $0.1 \mathrm{~mole} \mathrm{NaoH}(0.4 \mathrm{gNaOH}$ in $1000 \mathrm{ml}$ distilled water), using phenolphthalein indicator to an end point. The acidity was calculated as follows.

$\mathrm{T} . \mathrm{A}(\mathrm{mg} / \mathrm{l})=\quad$ Titre value $\mathrm{x} \times 50 \times 1000$

$$
100
$$

While $\mathrm{N}=$ Normality of $\mathrm{NaOH}=0.1$

T.A $(\mathrm{mg} / \mathrm{l})=$ Titre value $\times 0.1 \times 50 \times 1000$

\subsubsection{Titratable Alkalinity (TAL)}

This was also determined by the volumetric method, as reported in the methods of analysis in Association of Official Analytical Chemists (AOAC), (2005). $100 \mathrm{ml}$ of the paint effluent sample was titratedagainst $0.02 \mathrm{~N}$ $\mathrm{H}_{2} \mathrm{SO}_{4}$, using methyl red indicator. The alkalinity was calculated from the following:-

$\mathrm{TAL}=$ Titre value $\times \mathrm{N} \times 50 \times 1000$

$$
100
$$

TAL $(\mathrm{mg} / \mathrm{l})=$ Titre value $\times 0.02 \times 50 \times 1000$

$$
10 \overline{0}
$$

3.1 Table 1: Crude Paint Effluent

\section{Results And Tables}

\begin{tabular}{|l|l|l|}
\hline S/N & Measured Parameters & Analytical Values \\
\hline 1 & Temperature $\left({ }^{0} \mathrm{c}\right)$ & 28.90 \\
\hline 2 & Odour & ++++ \\
\hline 3 & Colour & ++++ \\
\hline 4 & $\mathrm{P}^{\mathrm{H}}$ & 8.0 \\
\hline 5 & Turbidity & 18.20 \\
\hline 6 & Conductivity $\mu$ s/cm & 950.0 \\
\hline 7 & Total Dissolved Solid (TDS) $\mathrm{mg} / \mathrm{l}$ & 450.0 \\
\hline 8 & Acidity $(\mathrm{mg} / \mathrm{l})$ & 120.0 \\
\hline 9 & Total Suspended Solid (TSS)mg/l & 900.0 \\
\hline 10 & Alkalinity $(\mathrm{Mg} / \mathrm{l})$ & 24.75 \\
\hline 11 & Total Solid $(\mathrm{mg} / \mathrm{l})$ & 1350.0 \\
\hline 12 & Oil \& Grease $(\mathrm{mg} / \mathrm{l})$ & 100.0 \\
\hline
\end{tabular}

\subsection{Table 2: M. oleifera- Treated paint effluent}

\begin{tabular}{|l|l|l|l|l|l|l|l|l|l|l|l|l|l|}
\hline S/N & Conc. & $\begin{array}{l}\text { TDS } \\
\mathrm{Mg} / 1\end{array}$ & Turb. & $\begin{array}{l}\text { Cond. } \\
\mu \mathrm{s} / \mathrm{m}\end{array}$ & $\begin{array}{l}\text { Oil/grea. } \\
\mathrm{Mg} / \mathrm{l}\end{array}$ & Odo. & Colo. & $\begin{array}{l}\text { Alk. } \\
\mathrm{Mg} / \mathrm{l}\end{array}$ & $\begin{array}{l}\text { Acid } \\
\mathrm{Mg} / \mathrm{l}\end{array}$ & $\begin{array}{l}\mathrm{Tss} \\
\mathrm{Mg} / \mathrm{l}\end{array}$ & $\begin{array}{l}\mathrm{Ts} \\
\mathrm{Mg} / \mathrm{l}\end{array}$ & $\mathrm{P}^{\mathrm{H}}$ & $\begin{array}{l}\text { Temp. } \\
{ }^{\circ} \mathrm{C}\end{array}$ \\
\hline 1 & $25 \mathrm{mg}$ & 390.0 & 7.2 & 810.0 & 90.0 & +++ & ++ & 28.0 & 23.0 & $\begin{array}{l}360 . \\
0\end{array}$ & 750.0 & 7.50 & 26.10 \\
\hline 2 & $50 \mathrm{mg}$ & 320.0 & 4.4 & 650.0 & 90.0 & + & + & 36.0 & 25.0 & $\begin{array}{l}220 . \\
0\end{array}$ & 540.0 & 7.50 & 26.30 \\
\hline 3 & $75 \mathrm{mg}$ & 290.0 & 3.0 & 600.0 & 90.0 & + & + & 34.0 & 27.0 & $\begin{array}{l}150 . \\
0\end{array}$ & 440.0 & 7.50 & 26.20 \\
\hline 4 & $100 \mathrm{mg}$ & 320.0 & 2.0 & 650.0 & 90.0 & + & + & 36.0 & 28.0 & $\begin{array}{l}100 . \\
0\end{array}$ & 420.0 & 7.50 & 26.20 \\
\hline 5 & $125 \mathrm{mg}$ & 320.0 & 1.8 & 650.0 & 90.0 & + & + & 40.0 & 32.0 & 90.0 & 410.0 & 7.50 & 26.30 \\
\hline 6 & $150 \mathrm{mg}$ & 320.0 & 1.2 & 650.0 & 90.0 & + & + & 34.0 & 36.0 & 60.0 & 380.0 & 7.50 & 26.30 \\
\hline
\end{tabular}




\subsection{Table 3: Control}

\begin{tabular}{|l|l|l|}
\hline S/N & Paramters measured & Analytical Values \\
\hline 1 & Temperature & 26.10 \\
\hline 2 & Odour & +++ \\
\hline 3 & Colour & +++ \\
\hline 4 & $\mathrm{P}^{\mathrm{H}}$ & 8.0 \\
\hline 5 & Turbidity & 18.2 \\
\hline 6 & Conductivity $\mu \mathrm{s} / \mathrm{cm}$ & 950 \\
\hline 7 & Total Dissolved Solid (TDS) $\mathrm{mg} / \mathrm{l}$ & 500 \\
\hline 8 & Acidity $(\mathrm{mg} / \mathrm{l})$ & 120.0 \\
\hline 9 & Total Suspended Solid (TSS) & 910 \\
\hline 10 & Alkalinity (Mg/l) & 24.70 \\
\hline 11 & Total Solid (mg/l) & 1410.0 \\
\hline 12 & Oil \&Grease (mg/l) & 98.0 \\
\hline
\end{tabular}

Legend: ++++ Very Heavy, +++ Heavy, ++ Moderate, + Slight.

\subsection{Fig. 1 Plot of Turbidity against Concentration of treated effluent}

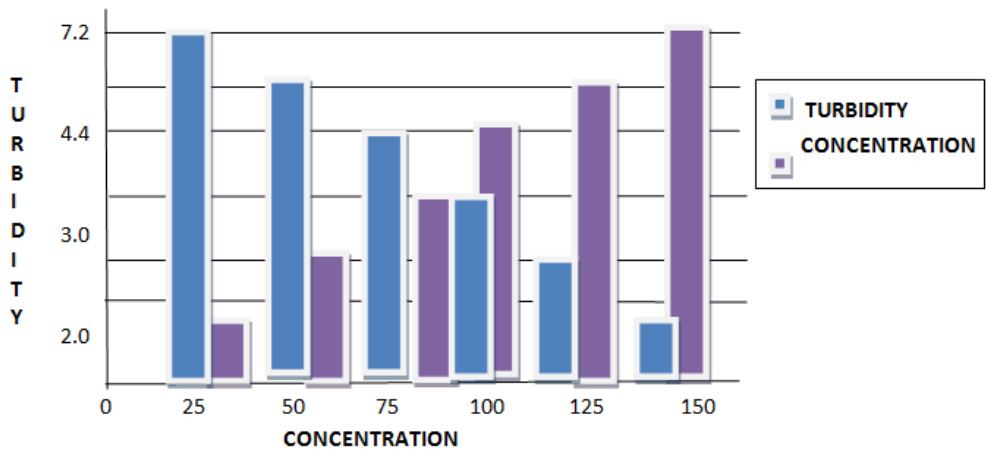

3.5 Fig. 2: Plot of TSS against Concentration of treated effluent

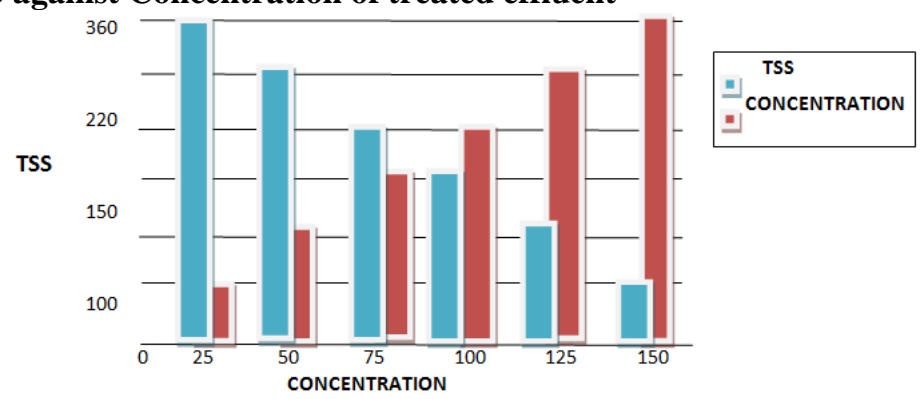

\section{Discussion, Conclusion And Recommendation}

Discussion:-

Effluent treatment strategy depends on the physico-chemical and biological properties of the effluent, and may involve some or all of the following methods:- chemical, physical and biological processes. The pre-treatment analysis of the effluent revealed that the effluent was of $\mathrm{P}^{\mathrm{H}}, 8.20$, with heavy odour and turbidity, suggestive of the presence of colloidal particles, which could include clay particles, microscopic organisms, coloured decaying vegetation, oil and grease, municipal wastes, and crustal substances.

When undisturbed, these particles would have large surface area relative to their weight, so that gravitational force would not influence their suspension, necessitating the high value of TSS and invariably, turbidity as recorded. The preliminary assessed parameters of TDS, TSS, TS, showed high level for each assessment, characteristic of polluted effluent. 
Post effluent treatment analysis showed that there were significant reductions in turbidity, total dissolved solids, orgarnoeleptic properties of colour and odour and total solids. This situation was more effective as the concentration of the powder increased from $25 \mathrm{mg}$ to $150 \mathrm{mg}$.

Chemical coagulant in effluent treatment destabilizes the suspended contaminants such that the particles make contact and agglomerate, forming floc that drops out of the solution by sedimentation (Nnamaniet al, 2012). Highly charged hydrolyzed metal ions such as aluminum sulphate (alum) leca, in solution reduce the repulsive forces between colloids by compressing the diffusing double layer surrounding individual particles, and the forces of attraction cause these particles to shift to each other, producing progressive agglomeration (Obiomaet al, 2012). This was observed in the moringaoleifera treated effluent sample which agreed favourably with earlier studies by different independent researchers, (Otuu, 2011; Nnamaniet al., 2012).

The moringaoleifera- treated paint effluent maintained fairly the same $\mathrm{P}^{\mathrm{H}}$ across the concentration gradient, bringing the $\mathrm{P}^{\mathrm{H}}$ from 8.20 in the crude effluent to 7.50

The alkalinity of $M$. oleifera treated paint effluent increased from $24.75 \mathrm{mg} / \mathrm{l}$ in crude sample to $40.0 \mathrm{mg} / \mathrm{l}$ post-treatment at a powder concentration of $125 \mathrm{mg} / 1$.

The acidity of the $M$. oleifera treated effluent showed a direct relationship with the concentration of the powder as the acidity increased from $23.0 \mathrm{mg} / \mathrm{l}$ at $25 \mathrm{mg}$ to $36.0 \mathrm{mg} / \mathrm{l}$ at $150 \mathrm{mg}$ concentration of the seed powder. Significantly, when compared with the untreated effluent with acidity of $120 \mathrm{mg} / 1$, the extract recorded $80.83 \%$ reduction in acidity at a concentration of $25 \mathrm{mg} / 1$, and $70 \%$ at a concentration of $150 \mathrm{mg} / 1$. Therefore moringaoleifera de-fatted seed powder was a very good effluent treatment bio-agent with respect to acidity of the effluent and could be recommended for such treatment where the acidity of the effluent discharge is a major environmental issue.

The conductivity of the $M$. oleifera treated crude paint effluent decreased from $810 \mu \mathrm{s} / \mathrm{cm}$ to $650 \mu \mathrm{s} / \mathrm{cm}$ between $25 \mathrm{mg} / \mathrm{l}$ concentration and $50 \mathrm{mg} / \mathrm{l}$ concentration of the powder and became fairly constant till $150 \mathrm{mg} / \mathrm{l}$. If compared with the original concentration of the untreated crude paint effluent with a conductivity of $950.0 \mu \mathrm{s} / \mathrm{cm}$, the treatment achieved only $14.74 \%$ reduction at concentration of $25 \mathrm{mg} / \mathrm{l}$ but improved to $31.58 \%$ as the concentration of the extract increased from $50 \mathrm{mg} / 1$ to $150 \mathrm{mg} / 1$. M .oleifera de-fatted seed powder is a poly-electrolyte. Highly charged poly electrolyte in solution reduces the repulsive forces between colloids by compressing the double layer surrounding the individual particles and the forces of attraction cause these particles to shift to each other, producing progressive agglomeration, thereby decreasing the population of the conductance species (Otuu, 2011).

In $M$. oleifera treated effluent, the turbidity reduced from 18.0-1.2, a difference of 16.8, representing $93.33 \%$ reduction at the concentration of $150 \mathrm{mg}$. since turbidity is a function of total suspended solid and total solid, this significant reduction would imply that $M$. oleiferade-fatted seed powder possessed an adsorptive property and could be recommended as a bio-flocculant for phyto-remediation of turbid paint effluent prior to discharge into the environment. Plots of turbidity, TSS, TS, against concentration of the extracts as shown in figures 1-3 showed an inverse relationship supporting the efficacy of the extract in bioflocculating activity.

\section{Conclusion And Recommendation}

The study proved that the N-Hexane de-fatted seed powder is a good bio-flocculating agent in the removal of turbidity and treatment of paint effluent. It is relatively inexpensive, environmental friendly, easy to use without the encumbrances of a sophisticated equipment and technical know-how. This good deturbidifier, de-colorizer and de-odorizing agent should be widely cultivated, and exploited for its adsorptive potential which makes it an ideal material for phyto-remediation of paint industrial effluent prior to discharge into the environment.

\section{References}

[1]. Angelica MarquetottiSalcedo Vieira, Marcelo F. Vieira, Gabriel F. Silva, Alvaro A. Araujo, Marcia R. Fagundes-Klen, Marcia T. Veit, and RosangelaBergamasco (2010), Use of MoringaOleifera Seeds as a Natural Adsorbent for Wastewater Treatment. Water Air Soil Pollution Brazil. Vol. 206:pp 273-281.

[2]. Amir Montakhao, Abdul Halim, Ghazali, Ghazali, MegatJohari B. MegatMohd. Noor Thamer Ahmed Mohamed, Badronnisabt. Yusuf (2010), Effects of Drying and Salt Extraction of MoringaOleiferaon its Coagulation of High Turbidity Water. Journal of America Science. Vol. 6(10): pp387-393.

[3]. Association of Official Analytical Chemists, AOAC, (2005). Methods of Analysis

[4]. Devletogluo O, Philipopoulos C., and Grigolopoulou H., (2002). Coagulation for treatment of paint Industry wastewater. J. Environ. Sci. Health, Part. A., 37:1361-1377.

[5]. Environmental and Human Resources Nigeria Limited (EHRL), 2012: Environment Impact Assessment of Paint Industry; Nigeria Environment Standard and Regulatory Agency (NESRA) Zonal Office, Okpara Avenue Enugu.

[6]. Nnamani, P.Obioma,Otuu, F. Chibuisi, Anthony A. Attama, Inya-Agha, Stella.I.,Ibezim C. Emmanuel (2012). Dry season turbid well water made fit in Enugu metropolis, Nigeria, "Water Management issues in Africa", Mauritus, Pp 40-41 (Accepted for publication March 2012 
[7]. Obioma Petra Nnamani, Franklin ChimaobiKnechukwuOkonkwoChigozie Chika and Fred ChibuisiOtuu (2012). Performance of prosopis Africana for remediation of malachite green contaminated aqua system. Scientific Research and Essays vol. pp. 41304137.

Otuu, Fred C. (2011) Evaluation of the flocculants and antimicrobial properties of Ethanol andaqueous extract of moringaoleifera seed powder on some well water samples in Enugu. Thesis submitted to the Nigerian Institute of Science Technology for the award offellowship of the Institute in Chemistry/Biochemistry (FNIST).

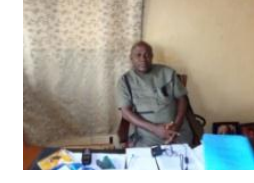

